\title{
Female Surfers Riding the Crest of a 'New Wave' of Irish National Identity
}

\author{
Rachael M.J. Telford, P. J. Kitchin and David Hassan \\ School of Sport, Ulster University, \\ Jordanstown, Northern Ireland
}

(C) Rachael M.J. Telford, Paul J. Kitchin \& David Hassan. This work is licensed under the Creative Commons Attribution-NonCommercial-NoDerivatives 4.0 International License. To view a copy of this license, visit http://creativecommons.org/licenses/by-nc-nd/4.0/.

\begin{abstract}
With surfing debuting at the 2021 Tokyo Olympics (postponed from summer 2020 due to the COVID 19 global pandemic) it is timely to consider surfing and the national identifications women in Ireland may have with this sport. As Lee Bush states, 'with so little scholarship on surfing women, descriptive studies are needed as a foundation for launching future interpretive and critical studies. " Twelve women who surf in Ireland spoke about the links their surfing may or may not have with their national identity. Previous academic inquiry on links between national identity and sport on the island of Ireland has almost exclusively focused on men's experiences of team sports and issues of 'Irishness'. 'Irishness' is globally recognised and stereotypically linked to traditional and indigenous Irish sports such as Gaelic football and a range of other cultural activities. Research into women's sport participation has largely been restricted to the study of soccer in the Republic of Ireland, ${ }^{3}$ and gendered evaluations of various lifestyle and health surveys. ${ }^{4}$ Katie Liston, a key researcher in sport and gender relations in Ireland, highlights that 'there seems to be an increasing diversity in the kinds of activities in which people participate in', 'and that there is a shift towards 'lifestyle' activities for adults as diversity increases in young people's participation in sports and leisure activities. Against the backdrop of Liston's work, this article delves deeper into data collected as part of a wider research project, discussing whether or not women who surf in Ireland do so as part of a process designed to construct and reflect their national
\end{abstract}

\footnotetext{
${ }^{1}$ Lee Bush, 'Creating Our Own Lineup: Identities and Shared Cultural Norms of Surfing Women in a U.S. East Coast Community', Journal of Contemporary Ethnography 45, no. 3 (2016): 290-318. https://doi.org/10.1177\%2F0891241614556346, 262.

${ }^{2}$ See the work of Alan Bairner, John Sugden, David Hassan and Mike Cronin for a broad range of work in this area.

${ }^{3}$ See for example Katie Liston, 'Women's Soccer in the Republic of Ireland: Some Preliminary Sociological Comments', Soccer \& Society 7, no. 2 (2006b): 364 - 384. Also see Ann Bourke, 'Women's Soccer in the Republic of Ireland: Past Events and Future Prospects', in Soccer, Women, Sexual Liberation: Kicking Off a New Era ed. Fan Hong and J.A. Mangan (London: Frank Cass, 2004): 162-82.

${ }^{4}$ Katie Liston, 'A Question of Sport' in Contemporary Ireland: A Sociological Map ed. Sara O'Sullivan (Dublin: University College Dublin Press, 2007), 159-180.

${ }^{5}$ Liston, 'A Question of Sport', 161.
} 
identities related to this arguably 'postmodern "6 'lifestyle sport', ${ }^{7}$ in which Ireland will be represented on the Olympic stage for the first time in 2021.

Keywords: Gender, Lifestyle sport, Surfing, National identity, Ireland

\section{Surfing in Ireland}

With Ireland geographically positioned off the northwest coast of Europe, it is surrounded by one of the most turbulent expanses of ocean in the world, the North Atlantic Ocean. The coastline reaching around from Portrush, County Antrim, in Northern Ireland to Tramore, County Waterford, in the Republic of Ireland consists of numerous beaches, reefs, coves, headlands and points. This coastline gets bombarded all year round by swells, and has attracted both Irish and foreign surfers to its world-class waves since the early 1960s. Ireland provides some of the most challenging surfing conditions in the world, which creates a specific type of wave and surfing style. ${ }^{8}$ The historical development of surfing in Ireland, and indeed the Irish roots of modern surfing, may provide an important historical foundation for understanding the relationships between surfing, gender and national identity in Ireland since its relatively recent arrival on the island, and help to explain the spectrum of responses of the surfers interviewed. The interviewees in this study, who grew up in areas where they had a lived experience of surfing as part of local and regional identity, may more readily associate surfing with their national identity, as they surfed on the Irish team at international competitions and lived in rural coastal communities with strong Irish traditions, in contrast to those who began to surf in later life, and had no lived experience of surfing beyond seeing it in films and in the media.

As with the history of the majority of sports, men's presence and dominance exists in surfing around the world, as in Ireland. The aim of this study was to investigate women who surf in Ireland, and their perceptions of how it could be linked to their national identity. In this Irish context, our research reveals that participation in surfing, and its apparent link to national identity, is threefold. Firstly, participation may be an expression and reimagining of Irish national identity for the women who surf on the national team, who come from the key surfing locations on the coast of Ireland; secondly, it may express a conscious distancing from other sports on the island with national identifications; or thirdly, it may have nothing whatsoever to do with any sense of national identity or imagining for women who surf. The vast majority of women who participate in surfing inhabit the latter two categories, and begin the sport later in life, in their thirties, and beyond, via 'Women's Weekends' funded by the Irish Sports Council aimed at encouraging women to be more active. These women tend to have no interest in the competitive side of surfing, but rather the escapist leisure experience of surfing, camaraderie with other women on these retreats, and simply being in the water.

The core of this article therefore rests on an innovative premise, which is that of a feminist study of women's participation and engagement (or lack thereof) in surfing in Ireland. The paper contributes to an expanding field of academic study in critical surf studies, Irish studies, gender studies and indeed feminist cultural studies. The findings in this article are also timely in light of the of the Tokyo Olympics, when Irish surfing will have its biggest

\footnotetext{
${ }^{6}$ The idea of lifestyle sport as postmodern sport is discussed in Belinda Wheaton, ed., Understanding Lifestyle Sports: Consumption, Identity and Difference (London: Routledge, 2004). Also see: Lincoln Allison, Amateurism in Sport: An Analysis and a Defence (London: Frank Cass, 2001); R. Rinehart, 'Emerging Arriving Sport: Alternatives to Formal Sport' in Handbook of Sports Studies ed. Jay Coakley and Eric Dunning (London: Sage, 2000), 504-519.

${ }^{7}$ The term is used by two leading researchers in the field. See Wheaton, Understanding Lifestyle; Rinehart, 'Emerging Arriving'.

${ }^{8}$ Different surfing styles evidenced around the world are noted by Wheaton, Understanding Lifestyle.
} 
international platform to date. With this increased visibility, surfing's popularity in Ireland may rise within the quiet costal locations in which it currently takes place and encroach on locally 'owned' surfing in Ireland. These are locations from which the Irish surf team and 'insider' surfers tend to originate. A more visible and fuller spectrum of surfing participants may begin to inhabit the waters of Ireland, from the core insiders of the sport, to the 'weekend warriors', to those who only partake as a leisure pursuit or want to buy into the surfing identity and lifestyle but have no aspirations of surfing on the national team or indeed being recognised as 'Irish' surfers. While the island of Ireland refers to both the Republic of Ireland and the British statelet of Northern Ireland, for the purposes of this article, and for ease of reading, the word 'Ireland' will be used to describe where the female surfers come from, regardless of the region in which they live.

\section{National identity and surfing in Ireland}

Broadly speaking, and in its simplest terms, nationalism can be described as a political ideology of nation building. National identity is therefore how people identify with this process within particular nations. Any national 'imagining"9 can therefore be recognised as one of three main theoretical perspectives on nationalism while the other two perspectives debate the origins of nationalism. ${ }^{10}$ Currently, there is a relative absence of academic work on women's gendered experiences of sport in Ireland, and resultantly there is little research on the gendered nature of women's national identity expressions in Ireland's surfing upon on which to build. It was therefore appropriate to review further research, from an array of other cross cultural contexts, to see how other researchers have investigated gender, sport and nationalism, and indeed surfing. ${ }^{11}$ As Malcolm MacLean states in his review of the Critical Surf Studies Reader, ${ }^{12}$

In recent years there has emerged a potent set of counter narratives of surfing - as a rigidly gendered site of production and performance of toxic forms of masculinity, increasingly challenged by women surfers; as a site of indigenous identity and nation building; and as a project of the early twentieth-century US leisure industries. As part of this revision, analysts have begun to rethink and reconceptualise surfing, surf cultures and the meaning of wave sliding. HoughSnee and Eastman's impressively inter-disciplinary collection is built around four broad themes: coloniality and decolonisation, race, ethnicity and identity, feminist critical geography, and

\footnotetext{
${ }^{9}$ Benedict Anderson, Imagined Communities (London: Verso, 1983).

${ }^{10}$ See Anthony D. Smith, Theories of Nationalism (London: Duckworth, 1983); Ernest Gellner, Culture, Identity, and Politics (Cambridge University Press, 1987).

${ }^{11}$ For examples in other geographical contexts, see Eduardo Archetti, Masculinity and Football: The Formation of National Identity in Argentina (Aldershot: Arena, 1994); J.A. Mangan and John Nauright, Sport in Australasian Society: Past and Present (London: Frank Cass, 2000); Patrick F. McDevitt, May the Best Man Win: Sport, Masculinity, and Nationalism in Great Britain and the Empire, 1880-1935 (New York: Palgrave Macmillan, 2004); Elaine Kim and Chungmoo Choi, Dangerous Women: Gender and Korean Nationalism (New York: Routledge, 1998); Suzanne Laberge and Mathieu Albert, 'Conceptions of Masculinity and of Gender Transgressions in Sport among Adolescent Boys’, Men and Masculinities 1, no. 3, (1999): 243-267, https://doi.org/10.1177/1097184X99001003001; Jim McKay, Michael A. Messner and Don Sabo, Masculinities, Gender Relations and Sport (Thousand Oaks: Sage, 2000); Claudio Tannsjo \& Tännsjö Tamburrini, eds., Values in Sport: Elitism, Nationalism, Gender Equality and the Scientific Manufacturing of Winners (London: Taylor \& Francis, 2000); Mervi Tervoc "Sports, "race" and the Finnish national identity in Helsingin Sanomat in the early twentieth century', Nations and Nationalism 8, no. 3 (2002): 335 - 356. https://doi.org/10.1111/1469-8219.00054; Emma Wensing \& Ton Bruce 'Bending the rules: Media representations of gender during an international sporting event', International Review for the Sociology of Sport 38, no. 4 (2003): 387-96. https://doi.org/10.1177\%2F1012690203384001; Joane Nagel 'Masculinity and Nationalism-Gender and Sexuality in the Making of Nations', Ethnic and Racial Studies 21 no. 2 (1998): 242269, https://doi.org/10.1080/014198798330007.

12 Dexter Z. Hough-Snee and Alexander S. Eastman, eds. The Critical Surf Studies Reader (Durham: Duke University Press, 2017).
} 
capitalism, economics and the commodification of surf culture. To a large degree these are the dominant themes in contemporary surf studies. ${ }^{13}$

Of particular relevance in Hough-Snee and Eastman's collection are three essays written in the feminist critical geography domain: 'Surfeminism, Critical Regionalism and Public Scholarship' by Krista Comer, 'Desexing Surfing' by Lisa Hunter and 'My Mother is a Fish: From Stealth Feminism to Surf Feminism' by Cori Schumacher. Other academic work, such as Surfing, Sex, Genders and Sexualities edited by Lisa Hunter (2018) and Scott Laderman's Empire in Waves: A Political History of Surfing (2014), provides analysis of surfing and surf culture. Two studies of women's surfing published by Irish surfer and academic Easkey Britton address contested spaces on the coast (2019) and the use of surfing as a medium to challenge and transform gender inequalities, have been illuminating in terms of the Irish context. Certainly Matt Warshaw's seminal work History of Surfing provides relevant historical information on women and surf culture more broadly; Kevin Cavey's How Green Was Their Wave: A History of Surfing in Ireland, as well as a number of articles about women's surfing in Ireland published by the Irish Surf Magazine Tonnta, provide historical contexts of surfing in Ireland. Awareness of the growing literature concerned with women, nationalism and citizenship which appears outside the field of sport is also helpful. ${ }^{14}$ On the whole, it is relatively easy to conclude that the study of sport, national identity, nationalism and nationality across a range of settings has largely been undertaken by men for men. Liston claims that 'historically, males have monopolised the organisation and administration of contact and team sports in Ireland as well as females' access to these "male preserves". ${ }^{15}$

Surfing in Ireland is not one of the main team sports on the island, or indeed a lifestyle choice traditionally associated with either of the two core Irish or British national identities present on the island in the same way that, for example, Gaelic football is linked to Irish national identity. Surfing is therefore more likely to be associated with national consciousness and identities, particularly of men, in other geographical locations around the world. The aim of this article is not to unpack or discuss the sociocultural history of surfing in Ireland, but rather to investigate, using a non-essentialist feminist framework, what women who surf on the island of Ireland have to say about issues of national identity. This type of investigation adds a new dimension and unique contribution to the broader field of research on national identity, Irishness, sport and gender; a lifestyle sport has not, as yet, been the focus of academic inquiry in this area. New findings and insights will be offered in relation to how gendered personal, sporting and ultimately national identities are socially constituted for female surfers that are located within the Irish national culture. This article also supports other academic research with regard to the 'space' versus 'place' debate in terms of national identity research, ${ }^{16}$ extending this to focus on women's experiences of surfing in Ireland. ${ }^{17}$ 'Space', that is the sea in which surfing takes place, is believed to be neutral and uncontaminated by stratified social variables such as gender and social class, which favour different groups of people in society. 'Place', however, is believed to be culturally constructed in ways that facilitate different meanings and expressions of identity for different groups of participants from different social backgrounds to become manifest. How 'places' such as these rural, Irish coastal towns and

\footnotetext{
${ }^{13}$ Malcolm MacLean, 'Review of the Critical Surf Studies Reader', Sport in History 40, no. 1 (2020): 147-149. 147.

${ }^{14}$ See Mary Maynard, 'Women's Studies', in A Companion to Gender Studies ed. Philomena Essed, Audrey Kobayashi and David Theo Goldberg (Oxford: Wiley-Blackwell, 2009), 29-39.

${ }^{15}$ Katie Liston, 'Sport and Gender Relations', Sport and Society 9, no. 4 (2006a): 616-633. https://doi.org/10.1080/17430430600768868

${ }^{16}$ Otmas Weiss, 'Identity Reinforcement in Sport: Revisiting the Symbolic Interactionist Legacy', International Review for the Sociology of Sport 36, no. 4 (2001): 393-405. https://doi.org/10.1177\%2F101269001036004002

${ }^{17}$ Weiss, 'Identity Reinforcement', 395.
} 
villages adapt, adopt and interpret surfing clearly plays a distinctive role in the gendered constitution of local, regional identities - as a more concentrated version of a broader national identity-for the women interviewed in this article. Indeed, Booth's work on Australian surfing also suggests that 'surfing subcultures adapt their values in relation to national agendas' ${ }^{18}$ This article therefore offers a new perspective on surfing and its links with national identity in a geographical context, in which the sport has never been part of the national consciousness of the majority of its people.

\section{Methods}

Guiding this study was a constructivist-interpretive approach, which views reality as socially constructed and emphasizes the lived experience of the knower over and above the investigator. Non-standardised, semi-structured interviews, were carried out with 12 women who surf in Ireland. The female surfers were from a range of geographical locations throughout the island, and demonstrated a spectrum of social backgrounds, ages and reasons for involvement in surfing. While some began surfing between the ages of 6 and 10 years of age - as a result of their families already being involved, and due to their location in coastal towns - others began in their late twenties or early thirties as a weekend activity which enabled them to extricate themselves from city life during the week. Purposeful and snowball sampling were used to recruit participants for this study, as part of wider study which also investigated other sports with stereotypical national identifications.

The aim of the interviews was to provide the most readily available medium for the expression of individual views, an opportunity not thought to exist as freely through the use of other survey instruments such as questionnaires. The purpose of the interviews was therefore to educe, for the first time in academic inquiry, the way in which women may use surfing as a means of reflecting, rejecting or renegotiating their national identities in Ireland. Although others may tell the story of the women interviewed in a different way, the postmodern feminist ontology deployed in this research was believed to provide a lens through which the different women's experiences of surfing could be studied and made sense of. Exploring the social construct of gender in an in-depth qualitative manner, and not attempting to quantifiably 'measure' it in any way, was the goal of the data collection phase. The social and political contexts which exist in Ireland were also considered as part of this feminist data collection, as it is believed gendered forms of identity are socially constituted and not biologically determined. For qualitative researchers, work is required that examines smaller case studies, enabling the experiences of a particular female population to be investigated in-depth instead of simply developing grand and sweeping generalisations of all females, which may prove inaccurate.

As the interviews progressed, transcripts were created from which data analysis developed along general principles of thematic analysis. ${ }^{19}$ Following familiarisation, initial codes identified meaningful sections of the transcripts. As patterns arose between the data, each interview was reviewed in light of the research aims and themes that were generated. Each theme was independently described, and examples of codes and text relating to these themes was produced to stimulate discussions between the researchers. In the next section of this article two main interlinking themes will be detailed in terms of how the female surfers in this study articulated the link, if any, that was expressed between surfing and their Irish national identities.

\footnotetext{
${ }^{18}$ Ormrod, 'Surf Rhetoric', 89.

${ }^{19}$ Kathy Charmaz, Constructing Grounded Theory: A Practical Guide Through Qualitative Analysis (London: Sage, 2006).
} 
These key themes are surfing as a potential site for the formation/reformation of Irishness in women surfers, and charting the complexities of Irishness in the global culture of surfing.

\section{Findings}

\section{Theme 1: Surfing as a potential site for the negotiation of Irishness for women who surf in Ireland.}

In this study three types of surfer were identified, with various levels of involvement apparent. They included what the interviewees themselves termed as the 'locals', the 'weekend warriors' and the 'trendies'.

Participants of lifestyle sports range from 'poseurs' buying into a desirable lifestyle to 'weekend warriors', the occasional participants who often participate in a range of different alternative and traditional sports, through to 'hard core' committed practitioners who are fully familiarised in the lifestyle argot, fashion, and technical skill of their activity, and spend considerable time, energy and often money doing it. ${ }^{20}$

Certainly, it was found that the participants in this study did not articulate a homogenous voice on issues of national identity and its links with their surfing. Instead what was evidenced was a spectrum of responses based on the surfers' level of immersion in local coastal surfing culture. However due to their continued and early immersion in surfing in rural, coastal, Irish towns, the 'local' women who grew up in the coastal towns were also more likely to compete for Ireland, and had experiences of their surfing being recognised and linked to their national identity at international competitions in a way that 'becoming aware of other cultures sharpens peoples' consciousness of their own domestic world and their distinctive national and cultural identities'. ${ }^{21}$ Undoubtedly, surfing reached Irish shores partly as a product of the forces of globalisation and as a result of the various influences of the media on surfing in the 1950s and $60 \mathrm{~s}^{22}$ Indeed, globalisation is best understood as a process of increasing, and increasingly reflexive, interconnectedness of individuals and collective social bodies in worldwide economic, political and cultural arenas. ${ }^{23}$ Moreover, in order for us to understand how this impacts on surfing in particular geographical contexts, we must have an appreciation of the different perspectives on globalization. ${ }^{24}$

In terms of theorizing globalised identities, at both the individual and national-cultural level, we might roughly divide globalisation theorists into three camps: those who argue that globalisation leads to increasing homogeneity, those who argue that it leads to increasing diversity or heterogeneity and those who suggest that it ultimately results in the hybridization of world cultures and political and economic systems. ${ }^{25}$ This article supports the latter two of these standpoints and supports the thesis that globalisation and global sports are creating a multitude of different, non-traditional ways in which particular national cultures can socially constitute various and intersecting types of gendered personal, sporting and national identities.

\footnotetext{
${ }^{20}$ Belinda Wheaton, 'Selling out? The commercialisation and globalisation of lifestyle sport' in The Global Politics of Sport: The Role of Global Institutions in Sport ed. Lincoln Allison (London: Routledge, 2005$), 141$.

${ }^{21}$ John Horne, Sport in Consumer Culture (Basingstoke: Palgrave, 2006), 133.

${ }^{22}$ See Douglas Booth, Australian Beach Cultures: The History of Sun, Sand and Surf (London: Frank Cass, 2001).

${ }^{23}$ According to Malcolm Waters, Globalisation (London: Routledge, 1995).

${ }^{24}$ See Jackie Hogan, 'The Construction of Gendered National Identities in the Television Advertisements of Japan and Australia', Media Culture Society 21 (1999): 743-758.

https://doi.org/10.1177\%2F016344399021006003

${ }^{25}$ Hogan, 'The Construction', 743.
} 
I think surfing is like a freedom of expression because I think with our climate [the political and social climate of Northern Ireland] it's nice to be able to do that [surfing] instead of having to be shoved into one or the other of either a traditionally recognised British/Protestant or Irish/Catholic sport(weekend warrior interviewee).

I'm not making a statement about my national identity through my involvement in surfing... I'm proud of who I am and where I come from but not in any xenophobic way that excludes others. I'm always open to and look forward to meeting new people from different places - we all have stories to tell... Depending on the context, I see myself as a citizen of Monaghan, Ireland, Europe, the world (weekend warrior interviewee).

Furthermore, this article specifically recognises and supports research that also rejects the idea that individual and national identities are becoming increasingly fragmented under conditions of globalisation. ${ }^{26}$ Therefore although surfing and surfing culture can be viewed as a product of the processes of globalisation, through the accelerated global flows of surfing products, fashions, surfing culture and indeed surfers themselves, this does not mean that individuals are becoming increasingly 'dis-embedded' and 'rootless' ${ }^{27}$ Conversely the insider /local surfers in this study were very confident and proud of their Irish national identities and understood that surfing only enhanced this identity still further, as opposed to fragmenting it.

Surfing makes us even prouder of where we are from and what we are doing...you never really heard of people promoting the Irish and the Irish culture through surfing... we've only started doing that quite recently when we realised what other cultures were doing to promote their own culture through the sport... so I think we are learning from other cultures how to promote our own culture which makes us stronger (local surfer interviewee).

Sometimes there seems to be an Irishness test, are you Irish? can you speak Irish? can you Irish dance? can you drink a bottle of whiskey? Like there are all these tests of nationality and that's just backward (local surfer interviewee).

While the act of surfing in the waters around Ireland may not be traditionally recognised by outsiders of this lifestyle surfing subculture as stereotypically 'Irish' in itself, there do appear to be factors within the physical coastal communities that influences how these surfers attribute specifically Irish elements to their surfing experiences and lifestyle expressions. These surfers were located at the outer edges of the island and normally at the coast, on the outskirts of largely rural towns and villages, where local Irish culture was already a large part of their lives and identities through Celtic art, Irish language, Irish music and Irish sport. Interestingly these women were found to regard surfing also as part of their local and regional Irish culture, and an activity that allowed them to experience waves distinct to Ireland.

Context and localisms are therefore important and indeed quite unique with regard to surfing in the British Isles and Ireland, as surfers in these colder water climates consume and transform their surfing identities to suit these conditions and localities. Whereas American surfers can romanticize surf lifestyles, Irish surfers, as found in this article, must adapt and transform globalised messages of surfing and refine them to be geographical and contextually appropriate. As Joan Ormrod writes, '[t]hese local conditions are responsible in part for the ways that global texts are hybridized and adapted to local conditions'. ${ }^{28}$ This local socially constituted negotiation of a more global sporting lifestyle supports previous findings in the

\footnotetext{
${ }^{26}$ Hogan 'The Construction', 743.

${ }^{27}$ As claimed in the work of Zygmunt Bauman, Intimations of Postmodernity (London: Routledge, 1992) and Anthony Giddens, Modernity and Self Identity: Self and Society in the Late Modern Age (Cambridge: Polity Press, 1991).

28 Joan Ormrod, 'Surf Rhetoric in American and British Surfing Magazines Between 1965 and 1976', Sport in

History 27, no. 1 (2007): 106. https://doi.org/10.1080/1746026070123107.
} 
Australian context. ${ }^{29}$ In her research, Hogan draws upon the work of Robertson who 'reconceptualizes globalising processes as a synthesis of the global and the local. He argues that the global and the local are not in opposition or competition, nor is one subsumed by the other: localism and globalism are bound together in the Janus-faced process of ' $\mathrm{g}$-localisation' ${ }^{30}$ This process known as ' $\mathrm{g}$-local-isation' is heavily influenced by global consumer trends and how the history of surfing in particular geographical contexts has developed. ${ }^{31}$ Indeed, Australian and American histories of surfing simply cannot be superimposed onto the Irish 'scene'.

The traditional image of Ireland is the drink and the Guinness and this is the standard you used to always see but the tourist boards (in Northern Ireland as well) -and rightly so-they have really jazzed up their campaigns - makes Ireland look more international, cool and trendy ...they'll still have the golfer and the Guinness and the old man in the paddy cap cycling up the street but they also show Easkey Britton and John McCarthy surfing in their ad (local surfer interviewee).

In fact, surfing in Ireland is beginning to become part of the national consciousness of people, particularly inhabitants of coastal towns that practice the sport. More broadly speaking, surfing is beginning to attract interest from the Irish Sports Council, the media and the Irish Tourist Board with regard to its potential not only as a new outlet to promote Ireland to tourists but also a means to get people on the island more involved in 'new' sports.

\section{Theme 2: Charting the complexities of Irishness in the global culture of surfing}

In Ireland, sports such as surfing may equally stand in opposition to traditional sports that are practiced in a particular geographical context by the 'dominant classes' ${ }^{32}$ In the context of Ireland, however, this is not necessarily the case. Surfing was not adopted by these insiders or 'locals' in opposition to the traditional and dominant sports in Ireland but was predicated upon their location near the coast and family involvement. These surfers and their families were also not thought to be rejecting the types of sports that the 'dominant' class were playing because often they were also members of this group. Indeed, in the rural coastal areas of Ireland, in which the majority of surfing locations are to be found, Gaelic football and other traditional recognisable Irish pastimes form part of the local vernacular. Surfers have practiced these pastimes, but have extended their Irish national imagining to also include their surfing involvement. Moreover, although the surfers interviewed chose surfing as their sport of choice, they did not feel they should be considered any less 'Irish' than, for example someone who played Gaelic football, or Irish danced, which are both recognised more widely as traditional Irish activities.

Sometimes I think there is too much emphasis put on traditional sports within this country and it's very hard to get coverage as an athlete who is in a sport that is not one of the mainstream ones. There are others sports with other Irish people involved that get ignored because the home grown sports are so dominant even though they are quite contained within Ireland...I don't play Irish sports anymore but I've still represented my country on numerous occasions in my sport so I'm representing Ireland as an Irish person in competition in my sport so I don't think that makes me any less Irish than someone who puts a G.A.A. jersey on every weekend (local surfer interviewee).

If you're Irish you're Irish no matter what sport you play as long as you still support your country and its people (weekend warrior interviewee)..Definitely surfing can be a way you can express your Irishness even though it's not one of the traditional Irish sports. (local surfer interviewee)

\footnotetext{
${ }^{29}$ Hogan 'The Construction', 743.

${ }^{30}$ Ibid., 744.

${ }^{31}$ A similar argument is made by Wheaton 'Selling out', 147. Also see Arhun Appadurai 'Disjuncture and difference in global cultural economy', Theory, Culture and Society 7, nos. 2-3 (1990): 97-119.

${ }^{32}$ Pierre Bourdieu, Distinction: A Social Critique of the Judgment of Taste (London: Routledge, 1984).
} 
For both the local surfers and weekend warriors, even though surfing is an individual as opposed to traditional team sport, Irishness was still important to them and could be expressed perfectly legitimately outside traditionally recognised Irish team sports such as Gaelic football. They also felt that like these traditional sports, surfing is a lifestyle, a community, and an identity reference point from which they could ascertain what their various and blended forms of gendered identities meant to them and how these can be influenced and performed in different locations and contexts. Certainly, in the context of Northern Ireland one interview stated that,

There's that solidarity that the Irish have that I think Protestants [in Northern Ireland] lack, I mean look at for starters they have got one church we have got how many different ones, overall I think it is harder for them to express like say a collective national identity (weekend warrior interviewee).

With these localisms in mind, it is argued that 'at least as rapidly as forces from various metropolises are brought into new societies they tend to be indigenised' is shown to be relevant. ${ }^{33}$ This process of indigenising may therefore explain the 'Irishness' the women interviewed as part of this work experienced and how they felt this became obvious through their surfing and the areas in which surfing was part of their regional culture. Also, if there is an indigenous dimension to the Irishness of their surfing and localities in which they live, this may explain why some of the interviewees found it difficult to explain why they felt this connection. Surfing can also expose its participants to other nationalities of surfers in the water, and can provide them with an opportunity to extend their 'national' imaginings so that they too can realise themselves as part of an 'imagined world' of surfers engaged with the sport at a global level outside of Ireland. ${ }^{34}$

As such, it is also possible that in certain cases people live in 'imagined worlds' and not just imagined communities. ${ }^{35}$ These 'worlds' are believed to affect the surfers in this study more so than for example other traditionally recognised 'Irish' sportspeople, such as Gaelic footballers, as the lifestyle sport in which they are involved is part of a global culture that extends beyond sport and into every facet of their daily lives. Surfing's global diffusion can therefore be regarded as having a type of global power which can create new types and gendered negotiations of identities which are socially constituted and located within particular national cultures. These new gendered negotiations of various forms of identities are the products of gender theories that support the idea that gender is socially constituted and not biologically determined. ${ }^{36}$ Therefore, as societies evolve and adapt to new ways of thinking and treating people, new opportunities open up that may not have been available to previous generations who may have been more constrained by gendered norms and values of genderappropriate behaviours.

Moreover understanding how surfing came to be established in Ireland and the differing experiences between generations of surfers in Ireland, is also important as it can provide a context through which to understand the linkages between surfing and national identity for the women in this study.

I think class has a lot to do with it because I think if you are from - I hate using class but do you know what I mean, working class areas in sort of inner cities where it is very much part of their culture to be immersed in one side or the other and hatred and you know that is very much part

\footnotetext{
${ }^{33}$ Arjun Appadurai, Modernity at Large: Cultural Dimensions of Globalisation (Minneapolis: University of Minnesota Press, 1996).

${ }^{34}$ For similar findings, see Wheaton, 'Selling Out'.

35 Appadurai, Modernity at Large, 296.

${ }^{36}$ See for example Judith Butler, Gender Trouble: Feminism and the Subversion of Identity (London: Routledge, 1999).
} 
of their identity, whereas people, it's not necessarily always the case, who have maybe got an education and got an opportunity to move out of those sort of areas into places where they can sort of remove themselves from the Troubles to a certain point...like travelling and I mean I think that's a big part of it now as well, it's the opportunity to get out of Northern Ireland and to experience other cultures and you know there is life outside of the Troubles and Northern Ireland and Catholics versus Protestants, because maybe people in sort of working class areas they don't get the opportunities, it's just a different mentality, ... its breeding and what you're bred into and the values that you grow up with. (weekend warrior interviewee)

\section{Influence of the family on negotiations of Irishness related to surfing}

How female 'insider' surfers various and blended forms of gender performances were socially constituted was found to be heavily dependent on how they were socialised into surfing from a young age by their families, and their proximity to renowned surfing destinations in Ireland such as Sligo, Donegal and Tramore. As one interviewee stated, 'surfing is just ingrained in my family and the area I live, I live by the coast so it was just natural for me to start surfing'. Also, another interviewee stated, 'I have surfing in my blood... I've grown up by the sea in Donegal, influenced by that area and the ocean all my life'. One of the surfers was even named after a renowned surfing location in County Sligo.

The most significant element with regard to the family was found to be the prominent roles that males played in introducing and encouraging these women to surf. Within these rural Irish, surfing communities, the surfers interviewed suggested that dichotomous gendered identities were not as apparent in their surfing experiences, and that a gendered sense of self was negotiated in a way that caused traditional, normative, socially constituted gender boundaries to become blurred. Although surfing can still, to a certain extent, be considered a male dominated alternative lifestyle choice in other geographical contexts, this did not appear to be entirely the case in Ireland. Instead, the women surfers interviewed stated that subcultural authenticity was more important in terms of their identity performances than challenging wider societal gender norms that may consider it 'inappropriate' for them as women to be surfing. These identity performances are significant, as they encompass the use of the body as a socially constituted symbol within society and indeed surfing therefore supports the arguments of feminists such as Judith Butler, who view gender as performative in nature as opposed to biologically determined. Indeed, these surfers therefore arguably use their bodies as national symbols when they surf at international competitions under the Irish flag, wear the Irish flag draped across their shoulders and wear traditional Irish symbols such as shamrocks on their clothes and surfboards. As one interviewee stated, 'I love wearing the Irish green and the shamrocks when we are away [at competitions] ... We wear big leprechaun hats and have the craic. ... we are proud to be recognized as Irish surfers'.

Traditional and stereotypical representations of Irish imagery are important to highlight because new and evolving expressions of Irish identity are becoming visible in the twenty-first century. Based on current literature on the topic, it would be axiomatic to say that global flows of information are subject to 'local responses and reformulations' ${ }^{37}$ These local responses and reformulations are particularly important to consider when addressing surfing in the context of Ireland with the unique social, cultural and political elements that inform the gendered national identity performances of the women who live there. Although 'a core theme of most of the traditional grand theories of the nature of globalisation has been the notion of modernisation as Westernisation or Americanisation' this is not believed to be true in the context of Ireland. ${ }^{38}$

\footnotetext{
${ }^{37}$ Appadurai, Modernity at Large, 47.

${ }^{38}$ J. Ford Nicholas and David Brown, Surfing and Social Theory: Experience, Embodiment and Narrative of the Dream Glide (Abingdon: Routledge, 2006), 48.
} 
As Friedman has noted, 'The content does not shape the container'. ${ }^{39}$ Therefore 'globalisation processes may offer some groups of consumers new post-national forms of global citizenship and identity'. ${ }^{40}$

In fact, as these females surfed with their male peers in these rural coastal localities, gendered forms of identity seemed to be ranked lower than one might imagine. This finding is important to consider. If gender does not play a significant role in how surfing identities are constituted and expressed in Ireland, gendered national identifications with regard to surfing may become irrelevant not only in the regional coastal surfing communities but also on the international competitive surfing circuit. Therefore, this group of 'insiders' are evidence of the modern sportswoman who only thinks about gender differences in her sporting performances if it is a contested and challenged topic. This discovery also is applicable to national identifications. If national identity is not something that is challenged in the everyday lives of these women, it becomes embedded in their sporting choice of surfing in a natural and evolving manner.

The interviewed surfers have means both economically and through family ties to explore their Irish national identities in different geographical contexts around the globe, and not only in competition. Indeed, all the 'insider' surfers interviewed in this research came from families with middle class parents; professionals who could fund their children's and their own involvement in surfing. Both economic and cultural capitals therefore enabled these surfers to travel and experience other cultures, giving them a type of cultural benchmark on which to assess their own Irish national identity both 'back home' and when away surfing internationally. Many competitive and commercially endorsed surfers had the resources, mainly through funding from their families, to travel to Australia, Fiji, Hawaii, Indonesia and America, to name but a few destinations, specifically to partake in surfing. These surfers may therefore be termed 'nomadic cosmopolitans' - those who use their sports career to journey. ${ }^{41}$ Cosmopolitanism, according to Urry, is the intellectual and aesthetic cultural disposition towards openness to peoples, places and experiences from different cultures. ${ }^{42}$ This type of cosmopolitan experience must impact of the negotiations and strengthening of Irishness for these 'locals', and how this related to them whilst in Ireland and abroad at competitions and travelling.

\section{Influence of the opportunity to surf \& compete internationally on 'Irish' surfing}

Personal economic capital linked to social class were therefore found to be important prerequisites for the opportunities available to these women. These social factors gave the women the currency, financially and socially, to allow this group of surfers to travel abroad with the prospects of experiencing other nationalities. This process was believed to result in a more liberal expression and awareness of their Irish national identities, as it allowed them to seek external references and meanings of what national identity was in other sociogeographical contexts, and how these applied to their own negotiations of national identity. They were therefore not isolated within Ireland and its own promotions of Irishness. These women could renegotiate what Irishness meant for themselves based on broader foreign life experiences outside of Ireland. For these women, national identity was not a topic that was

\footnotetext{
${ }^{39}$ Hogan, 'The Construction', 756; see also Jonathan Friedman, 'Global System, Globalisation and the Parameters of Modernity' in Global Modernities ed. Mike Featherstone, Scott Lash, and Roland Robertson (London: Sage, 1995), 87-8.

${ }^{40}$ Wheaton, 'Selling Out', 149.

${ }^{41}$ Joseph Maguire, Global Sport: Identities, Societies, Civilizations (Cambridge: Polity Press, 1999), 105.

42 John Urry, 'The Global Media and Cosmopolitanism', Department of Sociology, Lancaster University, Lancaster, 2003. https://www.lancaster.ac.uk/fass/resources/sociology-online-papers/papers/urry-globalmedia.pdf
} 
linked to exclusion. Instead, being secure in their national identities meant that they did not feel the need to prove their Irishness to anyone. These women therefore used surfing as a stage on which to express a lived expression of their Irish identities at a more imagined global level.

This competition environment is particularly important to appreciate, as it is at these events that surfers in this category felt most in touch with their Irish identities. At these competitions, Irish surfers had the opportunity to contextualise their surfing identities and to locate their identities as Irish surfers fitting into the global surfing scene. Outside of competition, when on surf trips around the globe, they also stated that immersion in other cultures helped them to appreciate what Ireland had to offer, and indeed instilled a sense of pride in them as they talked to others about surfing in Ireland and the world-class waves there.

When we are abroad people might be surfing in a professional event in Europe or something and when you're name's up on the scoreboard with GB beside it I'm always quick to change it say I'm Irish but for me it's nothing to do with politics or anything. I am also from Northern Ireland, so I do have that tie. I feel Irish because I live in Ireland...I feel Irish because I'm representing Ireland and because I surf on the Irish surf team(local surfer interviewee).

When travelling, being Irish defines who I am from others point of view as well as my own, the same for when I'm in Ireland and the part I come from. It defines my accent the people I grew up with and my traditions etc.... Being an Irish surfer does make you more hard-core to foreign people because of our environment... Also, Irish people have a good reputation of being a generous, friendly and humorous nation. It's nice to be part of that rather than one with a less desirable reputation (local surfer interviewee).

Being Irish - and being recognised as distinctly Irish when travelling - is significant as it enables 'insiders' to think about national identity when otherwise they may not have reason for such reflection. Indeed, as the surfer stated, recognising an Irish national identity is dependent on the opinions of others as well as the perceptions of the individual. It is also dependent on whether or not a person is externally or internally located with relation to their home environment. Indeed, as one interviewee stated, 'the part I come from' is infused with a more potent regional dimension to her broader 'Irish' identity when away travelling or at competitions. Also, the pleasing aesthetic of Irish national identity facilitates surfers, as detailed in the following quote, to be proud of where they are from in a way that becomes an intricate part of who they are.

It's kinda nice to meet people and go 'yeah I'm a surfer from Ireland' because the conditions we have here are quite extreme compared to other countries in the world and the Irish surfing community is a really close knit community as well which is something that is very rare in the world. So when you say 'I'm an Irish surfer' it has a lot attached to it, it's not just like you're a surfer from like any other country in the world there's like a story, a history and a family unit there.... [At international competitions] - for sure I'm proud that I'm Irish there. It's nice to reach out to other people but you go there, and you stand tall and say, 'yeah I'm Irish and I'm from Ireland'. We mightn't have a full team or the best team but we're here to compete and do the best that we can(local surfer interviewee).

This surfer therefore highlights that surfing offers new and different ways for Irish national identities to be recognised and expressed. Indeed, being an Irish surfer is more than simply being associated with an Irish flag at international competitions: it is a lived, close-knit community and indeed the expression of a regional identity within Ireland.

Surfing certainly has a role to play in my national identity because when I most often feel Irish is when I'm flying the flag at a surfing event. I don't think I'd be as into my nationality as much if I wasn't given the opportunities to represent my country and feel proud for doing that... I feel pretty proud to be Irish but I feel more proud to be Irish when we are away at competitions representing Ireland. So, when you're out of the country you feel it more, I think. I don't think 
about it as much at home but definitely when you're away and see an Irish flag or hear some Irish music and you're like 'awww it's home' (local surfer interviewee).

\section{Conclusions}

Overall, it is not surprising that the women from the 'insider' group linked their sense of Irishness to their surfing involvement, and that they did so for a variety of reasons. Not only did they compete on the Irish surfing team, they also lived and grew up in rural coastal Irish communities where Irish identity was omnipresent and something that was proudly emulated through a range of activities. The findings of this article also suggest that age is an important element in how gendered national identities are constituted on the part of women who surf in Ireland. This finding was especially the case if surfing was a lived part of the interviewees' regional identities from a very early age, through other family members being involved, as it seemed natural to equate Irishness with their surfing involvement in the locations in which they lived.

Generational differences are also important as they highlight how different historical contexts can produce different gendered experiences of how national identity can be articulated through certain sports. Related to this is the ways in which wider society, at different points in history, has allowed and enabled women to have a voice and a platform to discuss and express issues of national identity. This situation is particularly important to consider in the arena of sport, which has traditionally excluded women from meaningful involvement in a range of civic institutions. The surfers in this study therefore demonstrated that gender norms and gendered forms of identity do indeed change over time, and are in a constant state of flux, dependent upon a range of societal characteristics, localities and whether it was men or other women who introduced them to surfing.

What the surfers in this study represent collectively are women who are not only in tune with issues of national identity, but with whether or not this identity is linked to their surfing involvement. These women were also aware of the processes of globalisation and how it affected the socially constituted negotiations of their national identity. Women surfers were also able to extend this national 'imagining' still further. ${ }^{43}$ Not only were they able to envisage themselves as more than part of a particular nationalist 'imagined' community in Ireland, they were also able to locate their Irishness and surfing involvement within a more globalised imagined 'world' of surfers.

Overall, uncovering the experiences of the women who were interviewed as part of this study illuminates some of the core themes in academic work on surfing today. As MacLean highlights, counter narratives are emerging which provide a new lens through which to view surfing. Hough-Snee and Eastman's collection exemplifies new discourse on the tenets of identity, race, coloniality and commodification in a way that enables the academic domain to investigate and understand surfing - and how, like the women in this study, women may use surfing to express various and intersecting forms of identity. More research by surfers and academics such as Easkey Britton is refreshing and illuminating in the context of this study too, as the water around Ireland may provide a new, uncontested space for women to express themselves as we move further into the twenty-first century, and Irish surfing becomes more visible with its advent at the Tokyo Olympics in 2021.

\footnotetext{
${ }^{43}$ Anderson, Imagined Communities.
} 


\section{Bibliography}

Allison, Lincoln. Amateurism in Sport: An Analysis and A Defence. London: Frank Cass, 2001

Allison, Lincoln, ed. The Global Politics of Sport: The Role of Global Institutions in Sport. New York: Routledge, 2005.

Anderson, Benedict. Imagined Communities. London: Verso, 1983.

Anderson, Kristen. L. "Snowboarding: the construction of gender in an emerging sport." Journal of Sport and Social Issues, 23, no. 1(1999): 55-79. https://doi.org/10.1177\%2F0193723599231005

Appadurai, Arjun. "Disjuncture and difference in global cultural economy." Theory, Culture and Society 7, nos. 2-3 (1990): 97-119.

http://www.arjunappadurai.org/articles/Appadurai_Disjuncture_and_Difference_in th e_Global_Cultural_Economy.pdf

- Modernity at Large: Cultural Dimensions of Globalisation. Minneapolis: University of Minnesota Press, 1996.

Archetti, Eduardo. Masculinity and Football: The Formation of National Identity in Argentina. Aldershot: Arena, 1994.

Bairner, Alan. Sport, Nationalism and Globalization: European and North American Perspectives. Albany: SUNY Press, 2001.

Bauman, Zygmunt. Intimations of Postmodernity. London: Routledge, 1992.

Beal, Becky. "Disqualifying the official: an exploration of social resistance through the subculture of skateboarding." Sociology of Sport Journal 12 (1995): 252-267. https://doi.org/10.1123/ssj.12.3.252

Booth, Douglas. "Surfing: The cultural and technological determinants." Culture, Sport, Society 2, no. 1, (1999): 36-55. https://doi.org/10.1080/14610989908721828

Booth, Douglas. Australian Beach Cultures: The History of Sun, Sand and Surf. London: Frank Cass, 2001a.

Booth, Douglas. "From Bikinis to Boardshorts: Wahines and the Paradoxes of Surfing Culture". Journal of Sport History 28, no. 1 (2001b) 3-22. https://www.jstor.org/stable/43609829

Borden, Iain. Skateboarding, Space and the City: Architecture and The Body. Oxford, Berg, 2001.

Bottos, Lorenzo Canas and Natalie Rougier. "Generations on the Border: Changes in Ethnonational Identity in the Irish Border Area". Nationalism and Ethnic Politics 12, no. 3 (2006): 617 - 642 
Bourdieu, Pierre. Distinction: A Social Critique of the Judgment of Taste. London: Routledge, 1984.

Bourke, Ann. "Women's Football in the Republic of Ireland: Past Events and Future Prospects" in Soccer, Women, Sexual Liberation: Kicking Off a New Era, ed. Fan Hong and J.A. Mangan (London: Frank Cass, 2004): 162-82.

Britton Easkey. "Just add surf: The power of surfing as a medium to challenge and transform gender inequalities". In Sustainable Stoke: Transitions to Sustainability in the Surfing World ed. Gregory Borne and Jess Ponting (Plymouth, UK: Plymouth Sustainability and Surfing Research Group, 2020): 118-127.

Britton, Easkey, Rebecca Olive, and Belinda Wheaton. "Surfers and leisure: 'Freedom' to surf? Contested spaces on the coast" in Seascapes Symposium - Living with the Sea, Auckland, New Zealand, 16-19 February 2016. Abingdon: Routledge, 2019.

Bush, Lee. "Creating Our Own Lineup: Identities and Shared Cultural Norms of Surfing Women in a U.S. East Coast Community". Journal of Contemporary Ethnography 45, no. 3 (2016): 290-318. https://doi.org/10.1177\%2F0891241614556346

Butler, Judith. Gender trouble: feminism and the subversion of identity. $10^{\text {th }}$ anniversary edition. London: Routledge, 1999.

Charmaz, Kathy. Constructing Grounded Theory: A Practical Guides Through Qualitative Analysis. London, Sage, 2006.

Drummond, Murray. "Review of Australian Beach Cultures: The History of Sun, Sand and Surf, by Douglas Booth.” International Review for the Sociology of Sport 37, no. 2 (2002): 251-254

Evers, Clifton. "How to Surf”. Journal of Sport and Social Issues 30, no. 3 (2006): 269-243

Finney, Ben and James, D. Houston. Surfing: A History of the Ancient Hawaiian Sport. San Francisco: Pomegranate Artbook, 1996.

Ford, Nicholas J. and David Brown. Surfing and Social Theory: Experience, Embodiment and Narrative of the Dream Glide. Abingdon: Routledge, 2006.

Foucault, Michel. The History of Sexuality, Vol. 1: An Introduction. Translated by Robert Hurley. New York: Vintage Books, 1978.

—. Discipline \& Punish: The Birth of Prison. New York, NY: Vintage Books, 1979.

Friedman, Jonathan. Cultural Identity and Global Process. London: Sage, 1994.

. "Global System, Globalisation and the Parameters of Modernity" in Global Modernities ed. Mike Featherstone, Scott Lash, and Roland Robertson (London: Sage, 1995): 69-90. http://dx.doi.org/10.4135/9781446250563.n4 
Gellner, Ernest. Culture, Identity, and Politics. Cambridge: Cambridge University Press, 1987.

George, Sam. “When We Were Kings”. Surfer 40, no. 10 (1999): 142-162.

. The Perfect Day: 40 Years of Surfer Magazine. San Francisco: Chronicle, 2001.

Giddens, Anthony. Modernity and Self Identity: Self and Society in the Late Modem Age. Cambridge: Polity Press, 1991.

Hardt, Michael and Antonio Negri. Empire. Cambridge, Mass.: Harvard University Press, 2000.

Hogan, Jackie. "The construction of gendered national identities in the television advertisements of Japan and Australia”. Media Culture Society 21 (1999): 743-758. https://doi.org/10.1177\%2F016344399021006003

Holmes, Paul. "Surf Culture: A Serious Subculture" in The Next Wave: A Survey of World Surfing, ed. Nick Carroll (London: MacDonald, 1991): 199-205.

Horne, John. Sport in Consumer Culture Basingstoke: Palgrave, 2006.

Hough-Snee, Dexter Z. and Alexander S. Eastman. The Critical Surf Studies Reader. Durham: Duke University Press, 2017.

Jaggard, Ed. "Review of Australian Beach Cultures: The History of Sun, Sand and Surf by Douglas Booth". International Journal of the History of Sport 20, no. 3, (2003): 179180.

Kampion, Drew and Bruce Brown. Stoked: A History of Surf Culture. Koln: Evergreen, 1997.

Kampion, Drew and Bruce Brown. A History of Surf Culture. Los Angeles: General Publishing Group, 2003.

Kim, Elaine H. \& Chungmoo Choi. Dangerous Women: Gender and Korean Nationalism New York: Routledge, 1998.

Laberge, Suzanne and Mathieu Albert. "Conceptions of Masculinity and of Gender Transgressions in Sport among Adolescent Boys." Men and Masculinities 1, no. 3 (1999): 243-267 https://doi.org/10.1177/1097184X99001003001

Liston, Katie. "The Gendered Field of Irish Sport" in Ireland Unbound: A Turn of the Century Chronicle, ed. Mary, P. Corcoran and Michael Peillon (Dublin: Institute of Public Administration, 2002): 231-47.

Liston, Katie. "Some Reflections on Women's Sports" in Sport and the Irish: Histories, Identities, Issues, ed. Alan Bairner (Dublin: UCD Press, 2005a): 206-24.

- "Established-Outsider Relations between Males and Females in the Field of Sport in Ireland". Irish Journal of Sociology 14, no. 1 (2005b): 66-85 
. "Sport and Gender Relations". Sport and Society 9, no. 4 (2006a): 616-633. https://doi.org/10.1080/17430430600768868

. "Women's Soccer in the Republic of Ireland: Some Preliminary Sociological Comments". Soccer \& Society 7, no. 2 (2006b): 364-384. https://doi.org/10.1080/14660970600615450

—. "A Question of Sport" in Contemporary Ireland: A Sociological Map, ed. Sara O'Sullivan (Dublin: University College Dublin Press, 2007): 159-180.

MacLean, Malcolm. "Review of the Critical Surf Studies Reader." Sport in History 40, no 1 (2020): 147-149.

Maguire, Joseph. Global Sport: Identities, Societies, Civilizations. Cambridge: Polity Press, 1999.

Mangan, J.A. \& John Nauright. Sport in Australasian Society: Past and Present. London: Frank Cass, 2000.

Maynard, Mary. "Feminism and postmodernism in social theory" in Developments in Sociology, ed. Robert G. Burgess and Anne Murcott (Harlow, Essex: Prentice Hall, 2001): 99-120.

Maynard, Mary. "Women's Studies" in A Companion to Gender Studies, ed. Philomena Essed, Audrey Kobayashi and David Theo Goldberg (Oxford: Wiley-Blackwell, 2009): 29-39.

McDevitt, Patrick. F. May the Best Man Win: Sport, Masculinity, and Nationalism in Great Britain and the Empire, 1880-1935. New York: Palgrave Macmillan, 2004.

McGloin, Colleen. Surfing Nation(s) - Surfing Country(s). PhD diss., University of Wollongong, 2005.

McKay, Jim, Michael A. Messner and Don Sabo. Masculinities, Gender Relations and Sport. Thousand Oaks: Sage, 2000.

Muggleton, David. Inside Subculture: The Postmodern Meaning of Style. Oxford: Berg, 2000.

Nagel, Joane. "Masculinity and Nationalism-Gender And Sexuality in the Making of Nations" in Nations and Nationalism: A Reader, ed. Philip Spencer and Howard Wollmann (New Brunswick, NJ: Rutgers University Press, 2005): 110-132.

Ormrod, Joan. "Surf Rhetoric in American and British Surfing Magazines Between 1965 and 1976". Sport in History 27, no. 1 (2007): 88-109.

https://doi.org/10.1080/17460260701231075

Rinehart, Robert E. "Arriving Sport: Alternatives to formal sport" in Handbook of Sports Studies, ed. Jay Coakley and Eric Dunning (London: Sage, 2000): 504-519. 
Robertson, Roland. Globalization: Social Theory and Global Culture. London: Sage, 1992.

Skelton, Gill and Tracey Valentine. "Cool Places: An Introduction to Youth and Youth Cultures" in Cool Places: Geographies of Youth Cultures, ed. Gill Skelton and Tracey Valentine (London: Routledge, 1998): 1-34.

Smith, Anthony D. Theories of Nationalism. London: Duckworth, 1983.

Stahl, Roger. War Games: Citizenship and Play in Post-Industrial Militarism. PhD diss. Pennsylvania State University, 2004.

Stratton, Jon. "On the impossibility of Subcultural Origins" in Subcultures Reader ed. Ken Gelder and Sarah Thornton (NY: Routledge, 1997): 183-184.

Tannsjo, Claudio, and Tännsjö Tamburini, eds. Values in Sport: Elitism, Nationalism, Gender Equality and the Scientific Manufacturing of Winners. London: Taylor \& Francis, 2000.

Tervo, Mervi. "Sports, 'race' and the Finnish national identity in Helsingin Sanomat in the early twentieth century". Nations and Nationalism 8, no. 3 (2002): 335-356. https://doi.org/10.1111/1469-8219.00054

Thornton, Sarah. Club Cultures: Music, Media and Subcultural Capital. Cambridge: Polity Press, 1995.

Urry, John. "The Global Media and Cosmopolitanism”. Department of. Sociology, Lancaster University, Lancaster, 2003. https://www.lancaster.ac.uk/fass/resources/sociologyonline-papers/papers/urry-global-media.pdf

Waters, Malcolm. Globalisation. London: Routledge, 1995.

Wensig, Emma H. and Toni Bruce. "Bending the rules: Media representations of gender during an international sporting event". International Review for the Sociology of Sport 38, no. 4 (2003): 387-96. https://doi.org/10.1177\%2F1012690203384001

Weiss, Otmas. "Identity reinforcement in sport, revisiting the symbolic interactionist legacy." International Review for the Sociology of Sport 36, no. 4 (2001): 393-405. https://doi.org/10.1177\%2F101269001036004002

Wheaton, Belinda. "Just Do It: Consumption, Commitment and Identity in the Windsurfing Subculture”. Sociology of Sport Journal 17 (2000): 254-74. https://doi.org/10.1123/ssj.17.3.254

Wheaton, Belinda. "Selling out? The Commercialisation and Globalisation of Lifestyle Sport" in The Global Politics of Sport: The Role of Global Institutions in Sport, ed. Lincoln Allison (London: Routledge, 2005): 140-161.

Young, Nat. A History of Surfing. Angourie, NSW, Australia: Palm Beach, 1994. 